\title{
Analysis of the incidence of intraocular metastasis
}

\author{
Leonard Weiss
}

\begin{abstract}
The incidence of metastases to the uvea is compared with that in eight other (extraocular) target sites, in patients with metastatic primary carcinomas of the breast, colorectum, and lungs. The incidence of intraocular metastases from breast cancer is lower than in the eight other target organs surveyed; in the other primary cancers, the incidences were midway between those in the other sites, However, when the incidence of intraocular metastases is viewed in relation to the calculated numbers of cancer cells delivered via the arterial route, the uveal tract is the most highly favoured target site for the development of metastases per unit of delivered cancer cells.

(Brf Ophthalmol 1993; 77: 149-151)
\end{abstract}

It is now generally accepted that in common with the brain and bone marrow, the most frequent intraocular cancers are metastases.

The delivery of cancer cells to a target organ is an absolute requirement for metastasis. The incidence of haematogenous (arterial) metastasis, however, does not correlate directly with target organ blood flow, ${ }^{1}$ which provides an accurate index of cancer cell delivery. ${ }^{2}$ This disparity between cancer cell delivery and metastasis development at different sites is addressed by the so-called 'seed-and-soil' hypothesis of Paget, ${ }^{3}$ which recognises differential interactions between the cancer cells and target organs occurring after cancer cell delivery, which affect the incidence of metastatic involvement.

Recently, an analytical technique, by means of a metastatic efficiency index (MEI) has been developed, to quantitate and compare the propensities of different target sites for metastatic development. The MEI is calculated from the incidence of metastases in different organs in relation to their blood flow, and hence to the delivery of cancer cells. ${ }^{4}$ This technique is used here to evaluate intraocular sites as targets for metastasis from primary cancers of the breast, colorectum, and lungs, and to compare them with other target organs.

\section{Materials and methods}

INCIDENCE OF OCULAR METASTASIS

Suitable quantitative data for the present study of intraocular metastasis are sparse, compared with those in other sites. This is mainly because of exclusion of the eye from organs examined during routine autopsies, and the failure commonly to make ophthalmic examinations in patients with advanced metastatic disease. Comparisons of the incidence of intraocular metastases from different primary cancers must also take into account the differential incidence of the primary cancers themselves. Thus, intraocular metastases will be seen most often in patients with the most common primary cancers, including carcinomas of the breast $^{5}$ and bronchus. ${ }^{6}$ Some published data concern the incidence of metastases in patients referred for ophthalmic examination because of ocular symptoms ${ }^{6-8}$; the relatively high incidence in these selected, symptomatic cases is inappropriately high for the calculation of overall incidence (for example, $38 \%$ reported by Mewis and Young ${ }^{8}$ ). Cases of local non-metastatic and/or regional disease are also inappropriate for the present study because, in the majority of cases, arterial metastases are generated by cancer cells released from metastases rather than directly from primary cancers. ${ }^{9-11}$ The involvement of metastatic 'cascades' of this type is suggested by the observation that in $85 \%$ of patients ocular metastases were associated with pulmonary metastases. ${ }^{12}$

The results of a literature search for series satisfying the above criteria, are summarised in Table 1 . The widely quoted incidence of metastasis reported by Bloch and Gartner (37\%), ${ }^{13}$ is clearly much higher than that in the other four reports $(8-10 \%)$. However, Ferry and Font ${ }^{14}$ have observed that Bloch and Gartner did not indicate whether the 'metastatic foci' observed by them were in fact metastases or intravascular cancer cell emboli. This discrimination is important because for many years it has been appreciated that most intravascular emboli do not in fact develop into metastase ${ }^{15}{ }^{16}$; the gross disparity between the large numbers of cancer cells entering the metastatic process and the relatively small numbers of metastases subsequently developing, has been termed 'metastatic inefficiency'. ${ }^{17}$ Therefore, in this study, the incidence of intraocular metastasis in patients with disseminated breast cancer will be taken as the weighted mean of $8.5 \%$, with Bloch and Gartner's high value discussed separately. This extimated mean incidence of $8.5 \%$ is in accord with that of $9 \cdot 7 \%$ given by Nelson et $a l,{ }^{18}$ who also give conservative estimates of $6.7 \%$ and $4 \cdot 2 \%$ for intraocular metastasis from bronchial and colonic carcinomas respectively.

Reports of the distributions of metastases within the eye itself vary considerably, although all indicate the preponderance of metastases in the posterior choroid. For example, in Shields and Shields ${ }^{19}$ series, $81 \%$ of intraocular meta-

Table 1 Incidence of ocular metastasis in patients with metastatic breast cancer

\begin{tabular}{lcr}
\hline Incidence (\%) & No of cases & Ref \\
\hline 8 & $4 / 52$ & 7 \\
8 & $11 / 135$ & 25 \\
$9 \cdot 2$ & $9 / 98$ & 8 \\
$9 \cdot 7$ & $3 / 31$ & 18 \\
37 & $19 / 52$ & 13 \\
\hline
\end{tabular}

Roswell Park Cancer. Institute, Buffalo, NY 14263, USA L Weiss 
Table 2 Incidence (\%) of target organ involvement

\begin{tabular}{|c|c|c|c|c|c|c|c|c|}
\hline Primary cancer & Kidneys & Brain & Bone & $\begin{array}{l}\text { Skeletal } \\
\text { muscles }\end{array}$ & Skin & Heart & Thyroid & Adrenals \\
\hline $\begin{array}{l}\text { Breast }^{\star} \\
\text { Colorectum† } \\
\text { Bronchi }\end{array}$ & $\begin{array}{l}17 \cdot 0 \\
13 \cdot 0 \\
22 \cdot 5\end{array}$ & $\begin{array}{l}22 \cdot 8 \\
11 \cdot 0 \\
42 \cdot 9\end{array}$ & $\begin{array}{l}61 \cdot 8 \\
27 \cdot 0 \\
32 \cdot 5\end{array}$ & $\begin{array}{r}15 \cdot 5 \\
3 \cdot 0 \\
-\end{array}$ & $\begin{array}{r}19.5 \\
5.0 \\
<1.0\end{array}$ & $\begin{array}{r}10 \cdot 3 \\
2 \cdot 0 \\
7 \cdot 5\end{array}$ & $\begin{array}{r}24 \cdot 0 \\
4 \cdot 0 \\
2 \cdot 5\end{array}$ & $\begin{array}{l}31 \cdot 2 \\
31 \cdot 0 \\
35 \cdot 6\end{array}$ \\
\hline \multicolumn{9}{|c|}{$\begin{array}{l}{ }^{\star} \text { Data from Weiss } \\
\text { †Data from Weiss et al } \\
\text { †Data from Abrams et al } \\
\text { †D }\end{array}$} \\
\hline
\end{tabular}

Target organs (blood flow, $\mathrm{ml} / \mathrm{min})^{\star}$

\begin{tabular}{|c|c|c|c|c|c|c|c|c|}
\hline Primary cancer & $\begin{array}{l}\text { Kidneys } \\
(1000)\end{array}$ & $\begin{array}{l}\text { Brain } \\
(750)\end{array}$ & $\begin{array}{l}\text { Bonet } \\
(600)\end{array}$ & $\begin{array}{l}\text { Skeletal } \\
\text { muscles } \\
(560)\end{array}$ & $\underset{(400)}{\text { Skin }}$ & $\begin{array}{l}\text { Heart } \\
(200)\end{array}$ & $\begin{array}{l}\text { Thyroid } \\
(100)\end{array}$ & $\begin{array}{l}\text { Adrenals } \\
(90)\end{array}$ \\
\hline $\begin{array}{l}\text { Breast } \\
\text { Colorectum } \\
\text { Bronchi }\end{array}$ & $\begin{array}{l}0.017 \\
0.013 \\
0.023\end{array}$ & $\begin{array}{l}0.030 \\
0.015 \\
0.057\end{array}$ & $\begin{array}{l}0.103 \\
0.045 \\
0.054\end{array}$ & $\begin{array}{l}0.028 \\
0.005 \\
-\end{array}$ & $\begin{array}{l}0.049 \\
0.013 \\
-\end{array}$ & $\begin{array}{l}0.051 \\
0.010 \\
0.038\end{array}$ & $\begin{array}{l}0.240 \\
0.040 \\
0.026\end{array}$ & $\begin{array}{l}0 \cdot 347 \\
0 \cdot 344 \\
0 \cdot 396\end{array}$ \\
\hline
\end{tabular}

^Blood flow data tabulated by Weiss ${ }^{4}$

tRed bone marrow

stases occurred in the choroid. However, too few cases are available for meaningful calculations of the individual incidence of metastasis in the ciliary body, iris, and retina.

BLOOD FLOW TO THE EYE

Few quantitative data are available for human choroidal blood flow. ${ }^{2021}$ Recent observations of pulsatile ocular blood flow, ${ }^{22}$ however, yielded a mean value of $0.628(0.040) \mathrm{ml} / \mathrm{min}$, and most of this is expected to supply the uvea.

In experimental animals detailed studies of organ blood flow have been made using radiolabelled microspheres, ${ }^{23}$ and Bill and his colleagues have made extensive use of labelled and unlabelled, $15 \mu \mathrm{m}$ microspheres to determine accurately the blood flow in different parts of the uvea and retina in anaesthetised animals. Following left ventricular injections into 15 monkeys (Macaca cynomolgus), counts indicated mean blood flows (SE) of $0.677(0.067) \mathrm{ml} / \mathrm{min}$ for the choroid; $0.008(0.001)$ for the iris; 0.081 $(0.006)$ for the ciliary body; and $0.034(0.002)$ for the retina. ${ }^{23}$ The total ocular blood flow in these primates was therefore approximately $0.8 \mathrm{ml} /$ min, which is remarkably close to the absolute value for humans, and which represents approximately $0.08 \%$ of cardiac output in these primates, ${ }^{24}$ in contrast to approximately $0.013 \%$ in humans.

Although there are well-known dangers in extrapolation of blood flow data from other animals to humans, the cited data for different parts of the primates' eyes are considered to justify the use of total blood flow as an approximation for choroidal blood flow in the present study.

METASTATIC EFFICIENCY INDICES FOR THE EYE The incidence of metastasis in various target sites was obtained from published autopsy data (Table 2), and the relative numbers of cancer cells delivered via the arterial route to these sites was assumed to be proportional to target organ blood flow, which was retrieved from the physio- logical literature. ${ }^{4}$ This assumption was based on experiments made in mice, where organ blood supply was estimated as fractions of total cardiac output, by performing $\gamma$ counts on organs removed from the animals shortly after left ventricular injection (LVI) of radiolabelled microspheres. These estimates of relative organ blood flow closely correlated $(r=0.99)$ with the delivery of radiolabelled cancer cells given by LVI. ${ }^{2}$

A metastatic efficiency index (MEI) was then calculated for individual target sites for each type of primary cancer":

$$
M E I=\frac{\% \text { incidence of involvement }}{\text { Blood flow }(\mathrm{ml} / \mathrm{min})}
$$

In a study of the involvement of eight target organs, excluding the eye, by metastases from 19 groups of primary cancers, sufficient data were available to calculate the MEIs in 135 of 152 possible cases. The MEIs of $65 \%$ of the 135 cases fell into the range of 0.01 to 0.09 (mean 0.027 (SD 0.018$)$ ); $15 \%$ fell into the MEI range of 0.000 to $0.009(0.005$ (SD 0.003)), which was interpreted as indicating a 'hostile' target organ environment, with a relatively low incidence of metastasis per 'unit' of cancer cells delivered to these sites and, in contrast, $20 \%$ fell into the $0 \cdot 1$ to 0.9 range $(0.277(\mathrm{SD} 0.129))$, indicating a 'friendly' environment with a relatively high incidence of metastasis per 'unit' delivered. The incidence of metastases and MEIs for primary cancers of the breast, colorectum, and bronchus are shown in Tables 2 and 3. As shown in Table 4 , in patients with metastatic breast, colonic, and bronchial cancers, the calculated values for MEI with respect to the eye are $13 \cdot 5,4 \cdot 2$, and $6 \cdot 7$ respectively.

Table 4 Metastatic efficiency indices (MEI) for intraocular metastasis

\begin{tabular}{llr}
\hline Primary site & Incidence of intraocular metastasis (\%) & $M E I^{\star}$ \\
\hline Breast & 8.5 & 13.5 \\
Colon & 4.2 & 6.7 \\
Bronchus & 6.7 & 10.7 \\
\hline
\end{tabular}

*alculated on the basis of an ocular blood flow of $0.628 \mathrm{ml} / \mathrm{min}^{22}$ 


\section{Discussion}

The incidence of intraocular metastases from breast carcinomas (mean $8.5 \%$; mainly to the posterior choroid) is generally lower than in the eight other target sites (Table 1); it might therefore be concluded incorrectly that this is a relatively 'hostile' site for the growth of metastatic breast cancer cells.

In the case of colorectal and bronchial carcinomas, the incidence of intraocular metastases ${ }^{18}$ occupies a middle position among other target organs; it might therefore be incorrectly concluded that, for cancer cells from both of these primary lesions, the uvea occupies a median position in the hierarchy of target organs providing optimal conditions for metastatic development.

The hierarchies of target sites with respect to hostile or friendly interactions with cancers cells (that is, 'seed-and-soil effects ${ }^{3}$ ), cannot be based solely on the incidence of metastatic involvement because this would overlook differential delivery via the blood stream. However, incidence data can be used to calculate the frequencies with which intraocular metastases are expected to be encountered in clinical practice. ${ }^{514}$

The MEI values for the uvea as a target site for metastases from breast, colonic, and bronchial cancers are the highest calculated for any investigated cancer in any investigated target site. ${ }^{4}$ It is extremely unlikely that the high values of MEI are due to incorrect estimates of ocular blood flow: on the one hand, if ocular blood flow in humans is lower than $0.628 \mathrm{ml} / \mathrm{min}$, this would serve to increase the values of MEI still further. On the other hand, if blood flow was underestimated by as much as a factor of 10 , the MEI would still have values in the high MEI range, characteristic of a 'friendly' site. Parenthetically, if the high incidence of intraocular metastasis of $37 \%$ reported by Bloch and Gartner ${ }^{13}$ is used, with all of the above values of blood flow, the MEI would be even higher.

Comparison of the MEI value of 13.5 for primary breast cancer with that for the adrenals $(0.347$; Table 3$)$ is particularly interesting, because the adrenals were previously considered to be the most favoured target sites for metastatic breast cancer and, next to bone marrow, also have the highest detected incidence of involvement.

In the case of primary bronchial and colonic carcinomas, the intraocular MEIs of $10 \cdot 7$ and $6 \cdot 7$ respectively, are considerably higher than those for the adrenals $(0.396$ and 0.344$)$, which previously were considered to have the highest values for metastases from these primary lesions.

It will be noted that no attempt is made to identify and stage the three types of primary breast, colonic, and bronchial carcinomas used in the present study; these data were not available! In addition, a literature search failed to find detailed reports of sufficient numbers of cases of ocular metastasis from other types of primary cancers for this type of analysis. Hopefully, this report will stimulate routine opthalmic examination of large numbers of patients with advanced metastatic cancer.

1 Weiss L. Mechanisms of metastatic patterns. In: Principles of metastasis. Orlando, FL: Academic, 1985: 200-56.

2 Weiss L, Ward PM, Harlos JP, Holmes JC. Target organ patterns of tumors in mice following the arterial disseminapatterns of tumors in mice following the arterial dissemina-

3 Paget $S$. The distribution of secondary growths in cancer of the breast. Lancet 1889; i: 571-3.

4 Weiss $L$. Comments on hematogenous metastatic patterns in humans as revealed by autopsy. Clin Exp Metastasis 1992; 10: 191-9.

5 Merrill CF, Kaufman DI, Dimitrov, NV. Breast cancer, metastatic to the eye is a common entity. Cancer 1991; 68: 623-7.

6 Stephens RF, Shields JA. Diagnosis and management of cancer metastatic to the uvea: a study of 70 cases. Ophthalmology 1979; 86: 1336-49.

7 Albert DM, Rubinstein RA, Scheie HG. Tumor metastases to the eye. Part 1 . Incidence in 213 patients with generalized malignancy. Am $\mathcal{F}$ Ophthalmol 1967; 63: 723-6.

8 Mewis L, Young SE. Breast carcinoma metastatic to the choroid. Ophthalmology 1982; 89: 147-51.

9 Travers B. Observations on the local diseases termed malignant. Medico-Chir Trans 1829; 15: 195-262.

10 Blumenson LE, Bross IDJ. A mathematical analysis of the growth and spread of breast cancer. Biometrics 1969; 25: 95grow.

11 Weiss L, Grundmann E, Torhorst J, Hartveit F, Moberg I, Eder $M$, et al. Haematogenous metastatic patterns in colonic carcinoma: an analysis of 1541 necropsies. F Pathol 1986; 150: 195-203.

12 Ferry AP. Metastatic carcinoma of the eye and ocular adnexa. Int Ophthalmol Clin 1967; 7: 615-58.

13 Bloch RS, Gartner S. The incidence of ocular metastatic carcinoma. Arch Ophthalmol 1971; 85: 673-5.

14 Ferry AP, Font RL. Carcinoma metastatic to the eye and orbit. 1. A clinicopathologic study of 227 cases. Arch Ophthalmol 1974; 92: 276-86.

15 Goldmann E. Growth of malignant disease in man and the lower animals with special reference to the vascular system. Proc $R$ Soc Med 1907; 1: 1-13.

16 Iwasaki T. Histological and experimental observations on the destruction of tumour cells in the blood vessels. F Path Bacteriol 1915; 20: 85-105.

17 Weiss L. Metastatic inefficiency. Adv Cancer Res 1990; 54: 159-211.

18 Nelson CC, Hertzberg BS, Klintworth GK. A histopathologic study of 716 unselected eyes in patients with cancer at the time of death. Am F Ophthalmol 1983; 95: 788-93.

19 Shields JA, Shields CL. Metastatic tumors to the intraocular structures. In: Intraocular tumors. Philadelphia: Saunders, 1992: 207-38.

20 Bill A. Ocular circulation. In: Moses RA, ed. Adler's physiology of the eye. St Louis: Mosby, 1981: 184-203.

21 Bill A. Circulation in the eye. In: Renkin EM, Michel CC, eds. Handbook of physiology - the cardiovascular system IV. Handbook of physiology - the cardiovascular system IV. American $22,1001-34$.

22 Langham ME, Kramer T. Decreased choroidal blood-flow associated with retinitis pigmentosa. Eye $1990 ; 4$ : 374-81.

23 Alm A, Bill A, Young FA. The effects of pilocarpine and neostigmine on the blood-flow through the anterior uvea in monkeys. A study with radioactively labelled microspheres. Exp Eye Res 1978; 15: 31-6.

24 Grossman J. In: Altman PL, Dittmer DS, eds. Respiration and circulation. FASEB: Bethesda, MD, 1971: 324 and 327.

25 Cade S. Ann Sci Session. American Cancer Society: New York, 1956: (cited in ref 26).

26 Orenstein MM, Anderson DP, Stein JJ. Choroid metastasis. Cancer 1972; 29: 1101-7.

27 Weiss L. Principles of metastasis. Orlando, FL: Academic, 1985: 162.

28 Abrams HL, Spiro R, Goldstein N. Metastases in carcinoma. Analysis of 1000 autopsied cases. Cancer 1950; 3: 74-85. 